\title{
Author Correction: The genome of Nautilus pompilius illuminates eye evolution and biomineralization
}

Yang Zhang (iD, Fan Mao, Huawei Mu, Minwei Huang (D), Yongbo Bao, Lili Wang, Nai-Kei Wong, Shu Xiao (D), He Dai, Zhiming Xiang, Mingli Ma, Yuanyan Xiong, Ziwei Zhang (D), Lvping Zhang, Xiaoyuan Song, Fan Wang, Xiyu Mu, Jun Li, Haitao Ma, Yuehuan Zhang, Hongkun Zheng (D), Oleg Simakov (iD and Ziniu Yu (D)

Correction to: Nature Ecology \& Evolution https://doi.org/10.1038/s41559-021-01448-6, published online 10 May 2021.

In the version of this Article initially published, there was an omission in the Data availability statement. The statement has been amended to now include the following: "Gene annotation data have been deposited in the Genome Warehouse database of the Genome Sequence Archive (GSA) under accession no. GWHBECW00000000."

The changes have been made to the online version the article.

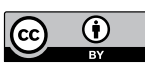

Open Access This article is licensed under a Creative Commons Attribution 4.0 International License, which permits use, sharing, adaptation, distribution and reproduction in any medium or format, as long as you give appropriate credit to the original author(s) and the source, provide a link to the Creative Commons license, and indicate if changes were made. The images or other third party material in this article are included in the article's Creative Commons license, unless indicated otherwise in a credit line to the material. If material is not included in the article's Creative Commons license and your intended use is not permitted by statutory regulation or exceeds the permitted use, you will need to obtain permission directly from the copyright holder. To view a copy of this license, visit http://creativecommons.org/ licenses/by/4.0/.

Published online: 28 September 2021

https://doi.org/10.1038/s41559-021-01571-4

(C) The Author(s) 2021 